\title{
The tripartite symbiosis between legumes, rhizobia and indigenous mycorrhizal fungi is more efficient in undisturbed soil
}

\author{
A. de Varennes ${ }^{\mathrm{a}, *}$, M.J. Goss ${ }^{\mathrm{b}}$ \\ ${ }^{a}$ Department of Agricultural and Environmental Chemistry, Instituto Superior de Agronomia, Technical University of Lisbon (TULisbon), \\ Tapada da Ajuda, 1349-017 Lisboa, Portugal \\ ${ }^{\mathrm{b}}$ University of Guelph, Kemptville Campus, P.O. Box 2003, 830 Prescott Street, Kemptville, Ont., Canada K0G 1 JO
}

Received 26 January 2007; received in revised form 10 April 2007; accepted 10 May 2007

Available online 30 May 2007

\begin{abstract}
We investigated how the rate of colonization by indigenous arbuscular mycorrhizal fungi (AMF) affects the interaction between AMF, Sinorrhizobium meliloti and Medicago truncatula Gaertn. To generate a differential inoculum potential of indigenous AMF, five cycles of wheat, each of 1 month, were grown in sieved or undisturbed soil before $M$. truncatula was sown. The early colonization of $M$. truncatula roots by indigenous AMF was faster in undisturbed soil compared with sieved soil, but by pod-fill the frequency of hyphae, arbuscules and vesicles was similar in both treatments. At this latter stage, M. truncatula grown in undisturbed soil had accumulated a greater biomass in aboveground tissues, had a greater $\mathrm{P}$ concentration and derived more $\mathrm{N}$ from the atmosphere than plants grown in disturbed soil, although soil compaction resulted in plants having a smaller root system than those from disturbed soil. The difference in plant $\mathrm{P}$ content could not be explained by modifications in hydrolytic soil enzymes related to the P cycle as the activity of acid phosphatase was greater in sieved than in undisturbed soil, and the activity of alkaline phosphatase was unaffected by the treatment. Thus, the results observed were a consequence of the different rates of AMF colonization caused by soil disturbance. Together with earlier results for soybean, this study confirms that soil disturbance modifies the interaction between indigenous AMF, rhizobia and legumes leading to a reduced efficacy of the bacterial symbiont.
\end{abstract}

(C) 2007 Elsevier Ltd. All rights reserved.

Keywords: Medicago truncatula; Interaction; $\mathrm{N}_{2}$ fixation; Arbuscular mycorrhizal fungi; Soil disturbance, Rhizobia

\section{Introduction}

Many legumes form symbioses with both rhizobia and arbuscular mycorrhizal fungi (AMF). Dual inoculation with both microorganisms results in a tripartite mutualistic symbiosis and generally increases plant growth to a greater extent than inoculation with only one (for a review see Chalk et al., 2006). There is now evidence that both enhanced acquisition of $\mathrm{P}$ by the host and effects on molecular signalling between the three symbionts may explain the synergism of AMF and rhizobia. Flavonoids are thought to be key signal compounds associated with the establishment of the tripartite symbiosis and Antunes et al. (2006a, b) reported that the presence of both symbionts

\footnotetext{
*Corresponding author. Tel.: + 35121 3653548; fax: + 351213653180 .

E-mail address: adevarennes@isa.utl.pt (A. de Varennes).
}

changed the accumulation of flavonoids in soybean roots. Overall, the root content of daidzein was reduced when Glomus clarum was present, whereas genistein and coumestrol only decreased when soybean plants (Glycine max (L.) Merr.) were inoculated with both G. clarum and Bradyrhizobium japonicum.

Goss and de Varennes (2002) studied the interaction of soybean, B. japonicum and indigenous AMF. They generated a differential inoculum potential for AMF by growing maize (Zea mays L.) in sieved or undisturbed soil before soybeans were sown. The soybean plants grown in undisturbed soil developed faster and accumulated a greater biomass than plants from disturbed soil. Moreover, there was a positive interaction between the two microbial symbionts in undisturbed soil that resulted in more abundant colonization of soybean roots by both microbes. By pod-fill, the frequency of hyphal, arbuscular 
and vesicular colonization was greater in undisturbed than in sieved soil. At this stage, nodule weight and the percentage of $\mathrm{N}$ derived from the atmosphere was also greater in undisturbed than disturbed soil.

The effect of the extent of AMF colonization on the efficacy of the tripartite symbiosis has only been shown for one crop (soybean), one soil (a gleyed Melanic Brunisol

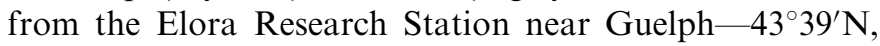
$80^{\circ} 25^{\prime} \mathrm{W}$ ) and one bacterial symbiont (B. japonicum) (Goss and de Varennes, 2002).

The hypothesis we tested was that this is a common phenomenon, and should therefore be observed using a very different combination of soil, plant and microbial symbionts, especially the bacteria.

\section{Materials and methods}

The experiment took place under greenhouse conditions (minimum temperature: $8{ }^{\circ} \mathrm{C}$; maximum temperature: $25^{\circ} \mathrm{C}$ ) and comprised two phases. In the first phase, the objective was to promote indigenous mycorrhizal development within the soil and establish a differential potential through contrasting soil disturbance. Eighteen pre-germinated seeds of wheat (Triticum aestivum L. cv Anza) were sown into each of eight pots containing $7 \mathrm{~kg}$ topsoil of a clay soil (Chromic Luvisol) from Revilheira, in southern Portugal $\left(38^{\circ} 28^{\prime} \mathrm{N}, 7^{\circ} 28^{\prime} \mathrm{W}\right)$. The soil, which had been passed through a $4 \mathrm{~mm}$ sieve before being packed into the pots to a bulk density of approximately $1.2 \mathrm{~cm}^{-3}$, contained $21 \mathrm{mg} \mathrm{N} \mathrm{kg}^{-1}$ as mineral $\mathrm{N}$ (extracted by $2 \mathrm{M}$ $\mathrm{KCl}$ ), $8 \mathrm{mg} \mathrm{P} \mathrm{kg}^{-1}$ and $58 \mathrm{mg} \mathrm{K} \mathrm{kg}^{-1}$ (Riehm,1958); the $\mathrm{pH}$ was 6.2 (1:2.5 in water). The soil received a basal dressing of $13 \mathrm{mg} \mathrm{P}$ and $30 \mathrm{mg} \mathrm{K} \mathrm{kg}^{-1}$ as calcium dehydrogenophosphate and potassium chloride, respectively.

One month after emergence, the shoots were measured and then excised, dried at $65^{\circ} \mathrm{C}$ for $48 \mathrm{~h}$, and weighed. The plant material from each pot was ground and analyzed for $\mathrm{N}$ and $\mathrm{P}$ contents. Four of the pots were taken and the soil passed through a $4 \mathrm{~mm}$ sieve. All root material collected on the sieve was cut into $2 \mathrm{~cm}$ long fragments and mixed with the soil. The soil was repacked in the pots to the same bulk density. Eighteen more pre-germinated wheat seeds were then sown (between the root systems left on the soil in the case of undisturbed soil) in all pots and again plants were excised 1 month after emergence. The process was repeated so that in total six cycles of wheat were carried out, five of which took place after the soil treatment was established.

In the second phase, the objective was to evaluate the growth, mycorrhizal development, nitrogen fixation and $\mathrm{P}$ content in a non-grain legume. Soil in the four pots was sieved again as described earlier and 19 pre-germinated seeds of an annual medic (Medicago truncatula Gaertn) were sown in each pot, four containing sieved soil and in the other four the soil remained undisturbed. Approximately $0.9 \mathrm{~g}$ of peat-based inoculum of Sinorrhizobium meliloti was placed at the bottom of the holes into which the seeds were placed, arranged into three rows. This ensured that the inoculum potential for $S$. meliloti was the same in the two disturbance treatments. The pots received $40 \mathrm{mg} \mathrm{N} \mathrm{kg}^{-1}$ supplied as a solution of ammonium sulphate enriched with $99.8 \%{ }^{15} \mathrm{~N}$ so that the source of $\mathrm{N}$ in the plants (from the soil or from the atmosphere) could be assessed. M. truncatula was harvested at 14 (first row), 29 (second row) and 56 days (third row) after emergence. The height and dry weight of the shoots were determined, and then these were ground for analysis of their $\mathrm{N}$ concentration (Dumas combustion) and $\mathrm{P}$ concentration (colorimetry after ashing the samples at $500{ }^{\circ} \mathrm{C}$ and dissolving in $0.3 \mathrm{M} \mathrm{HCl}$ ), and for the ratio of ${ }^{14} \mathrm{~N} /{ }^{15} \mathrm{~N}$ by mass spectrometry. Roots were examined for nodules, and those visible with the naked eye were enumerated. Roots were washed, weighed and then fixed in formyl acetic alcohol, cleared in $\mathrm{KOH}$, and stained with chlorazol-black $\mathrm{E}$ (Brundrett et al., 1984) before being examined for AMF colonization by the intersections method described by McGonigle et al. (1990).

At each sampling date, soil samples were taken from the pots, passed through a $2 \mathrm{~mm}$ sieve and analyzed for acid (EC 3.1.3.2) and alkaline phosphatase (EC 3.1.3.1) according to Eivazi and Tabatabai (1977).

Data were analyzed for variance by the General Linear Model (GLM) and mean separation was performed using the Newman-Keuls test at $p \leqslant 0.05$.

\section{Results}

The soil disturbance treatment had no significant effect on wheat. In fact, plant height, dry matter and $\mathrm{N}$ and $\mathrm{P}$ contents were not significantly different when overall averages for the five cycles were compared (data not shown).

Although the growth of the $M$. truncatula was not affected by soil disturbance over the first 14 days after emergence, it then accelerated in the undisturbed soil so that at flowering (29 days after emergence) and at pod-fill (56 days after emergence), the plants were taller than those grown in sieved soil (Table 1). By pod-fill, dry matter of plants from undisturbed soil was also significantly greater in undisturbed soil than in sieved soil.

Soil disturbance affected the time-course of AMF colonization of roots from M. truncatula. At 14 days after emergence, there was a greater frequency of fungal hyphae and arbuscules (65\% and $42 \%$, respectively) in the cortex of roots from undisturbed soil than in those from sieved soil ( $7 \%$ and $4 \%$ for hyphae and arbuscules, respectively). However, by pod-fill, there were no longer differences between disturbance treatments in the parameters of AMF colonization $(45 \%$ for hyphae, $22 \%$ for arbuscules and $11 \%$ for vesicles).

The concentration of $\mathrm{P}$ was always greatest in plants from undisturbed soil (Table 1), although the difference between treatments became smaller as plants aged, being more than $100 \%$ at 14 days after emergence but only about $10 \%$ at pod-fill. 
Table 1

Effect of differential soil disturbance (sieved or undisturbed) on biomass, $\mathrm{P}$ and $\mathrm{N}$ concentrations and contents and $\%{ }^{15} \mathrm{~N}$ atom excess in shoots of Medicago truncatula, and results from the analysis of variance using the General Linear Model

\begin{tabular}{|c|c|c|c|c|c|c|c|c|c|}
\hline Days after emergence & Treatment & $\begin{array}{l}\text { Shoot } \\
\text { height } \\
(\mathrm{cm})\end{array}$ & $\begin{array}{l}\text { Shoot dry } \\
\text { weight (g per } \\
\text { pot) }\end{array}$ & $\begin{array}{l}\text { Root fresh } \\
\text { weight (g per } \\
\text { pot) }\end{array}$ & $\begin{array}{l}\mathrm{P} \\
\left(\mathrm{g} \mathrm{kg}^{-1}\right)\end{array}$ & $\begin{array}{l}\text { P content } \\
\text { (mg per } \\
\text { pot) }\end{array}$ & $\begin{array}{l}\mathrm{N} \\
\left(\mathrm{g} \mathrm{kg}^{-1}\right)\end{array}$ & $\begin{array}{l}\mathrm{N} \text { content } \\
\text { (mg per } \\
\text { pot) }\end{array}$ & $\begin{array}{l}{ }^{15} \mathrm{~N} \text { atom } \\
\text { excess }(\%)\end{array}$ \\
\hline 14 & + & $5.1 \mathrm{a}$ & $0.23 \mathrm{a}$ & $0.35 \mathrm{a}$ & $0.90 \mathrm{~b}$ & $0.2 \mathrm{~b}$ & nd & nd & nd \\
\hline 14 & - & $5.3 \mathrm{a}$ & $0.25 \mathrm{a}$ & $0.35 \mathrm{a}$ & $1.94 \mathrm{a}$ & $0.5 \mathrm{a}$ & nd & nd & nd \\
\hline 29 & + & $9.6 \mathrm{~b}$ & $1.10 \mathrm{a}$ & $1.1 \mathrm{a}$ & $2.01 \mathrm{~b}$ & $2.2 \mathrm{~b}$ & $21 \mathrm{a}$ & $27 \mathrm{a}$ & nd \\
\hline 29 & - & $11.1 \mathrm{a}$ & $1.28 \mathrm{a}$ & $0.9 \mathrm{a}$ & $3.04 \mathrm{a}$ & $3.9 \mathrm{a}$ & $21 \mathrm{a}$ & $31 \mathrm{a}$ & nd \\
\hline 56 & + & $17.0 \mathrm{~b}$ & $2.33 \mathrm{~b}$ & $1.9 \mathrm{a}$ & $3.41 \mathrm{~b}$ & $7.9 \mathrm{~b}$ & $25 \mathrm{a}$ & $49 \mathrm{a}$ & $1.34 \mathrm{a}$ \\
\hline 56 & - & $18.3 \mathrm{a}$ & $2.58 \mathrm{a}$ & $1.4 \mathrm{~b}$ & $3.78 \mathrm{a}$ & $9.7 \mathrm{a}$ & $24 \mathrm{a}$ & $53 \mathrm{a}$ & $0.89 \mathrm{~b}$ \\
\hline \multicolumn{10}{|l|}{ Effect of treatment } \\
\hline Date & & $264.95^{* * *}$ & $633.56^{* * *}$ & $56.65^{* * *}$ & $49.90^{* * *}$ & $677.95^{* * *}$ & $25.53 * * *$ & $235.99 * * *$ & - \\
\hline Disturbance & & $4.91^{*}$ & $8.68^{* *}$ & $5.37^{*}$ & $21.17^{* * *}$ & $42.04^{* * *}$ & ns & $6.71^{*}$ & $57.09^{* * *}$ \\
\hline Date $\times$ disturbance & & ns & ns & ns & ns & $6.44^{* *}$ & ns & ns & - \\
\hline
\end{tabular}

For each date, values in a column followed by the same letter are not significantly different as estimated by the Newman-Keuls test at $p<0.05$. Treatments: + : sieved soil; - : undisturbed soil; nd: not determined; ns, *,**,***: $F$-values non-significant and significant at $p \leqslant 0.05, p \leqslant 0.01$ and $p \leqslant 0.001$, respectively.
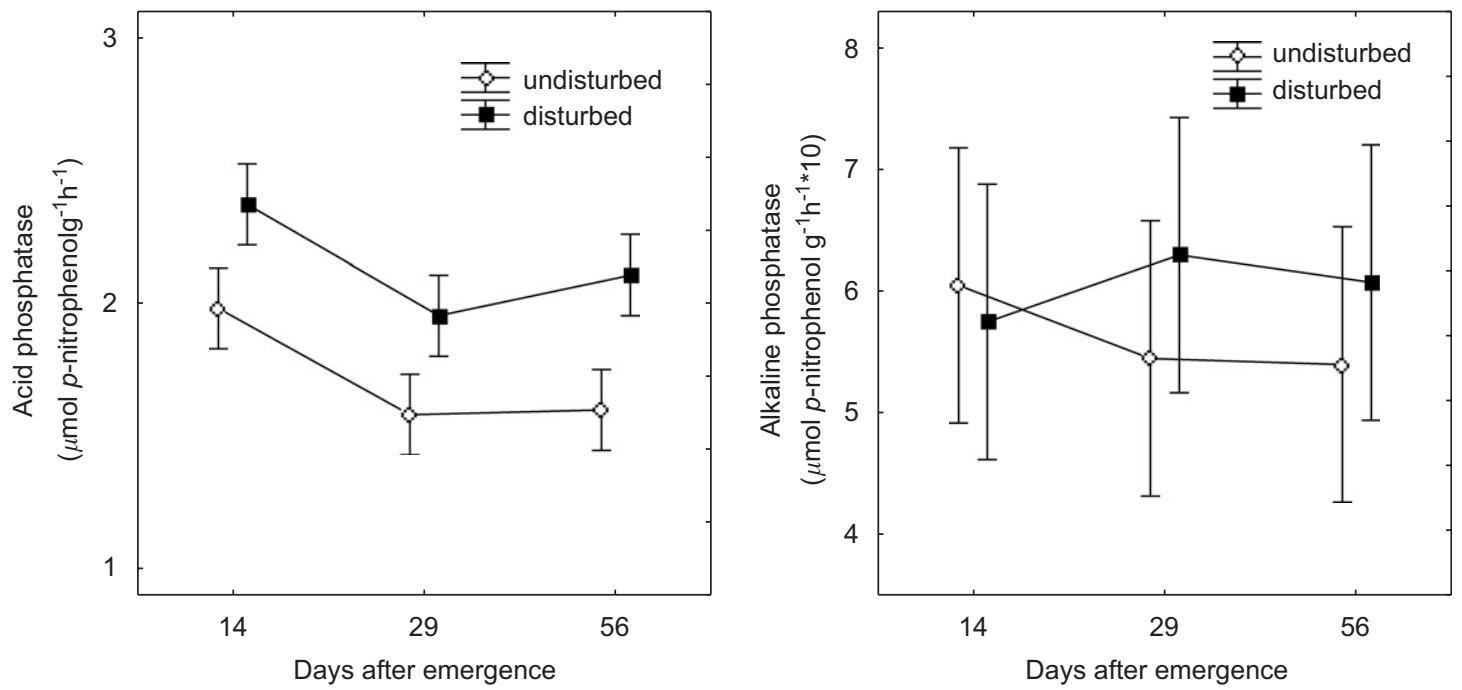

Fig. 1. Activities of acid (left) and alkaline phosphatases (right) in the soil. The vertical bars represent the $95 \%$ confidence intervals.

While the concentration of $\mathrm{N}$ was similar in both treatments, the $\mathrm{N}$ content was marginally greater in plants from undisturbed soil (significantly different according to the GLM, but not according to the Newman-Keuls test, Table 1).

The number of root nodules was similar for the disturbance treatments at 14 and 29 days after emergence ( 25 and 60 per plant, respectively). By pod-fill, the nodules from plants grown in undisturbed soil were considerably larger than those from sieved soil. However, because they were also more senescent, it was not possible to evaluate their number and weight, as they became easily detached from the roots when these were removed from the soil. This greater biomass of nodules was consistent with the ${ }^{15} \mathrm{~N}$ atom excess in shoots from plants grown in undisturbed soil being considerably smaller than that of plants grown in the sieved soil (Table 1). These confirmed that less $\mathrm{N}$ was derived from the soil in the first case, i.e. that biological $\mathrm{N}_{2}$ fixation was impaired in the sieved soil.

The activity of acid phosphatase was greater in sieved soil compared with undisturbed soil, but the activity of alkaline phosphatase was not affected by treatment (Fig. 1).

\section{Discussion}

Most of the previous research on the interaction of AMF and rhizobia concerning growth and acquisition of $\mathrm{P}$ and $\mathrm{N}$ by legumes took place with and without inoculation with AMF, often in sterilized media to eliminate the influence of indigenous AMF. In general, results from these studies have shown that dual inoculation with AMF and rhizobia increase plant growth and $\mathrm{N}_{2}$ fixation to a greater extent than inoculation with only one microorganism 
(Vejsadova et al., 1992, 1993; George et al., 1995; Ibijbijen et al., 1992; Antunes et al., 2006a). As a consequence of the large number of studies already available, it is commonly accepted that there is a mutualistic tripartite symbiosis between AMF, rhizobia and legumes.

The study of Goss and de Varennes (2002) with soybean suggested that not only the presence but also the extent of AMF colonization would determine the efficacy of the tripartite symbiosis. Their work relied entirely on creating a differential inoculum of indigenous AMF. In part, this approach was encouraged by the need for a greater understanding of the basic biology and diversity of AMF (Abbott et al., 1995) and the recognition of practical limitations to the use of introduced inoculum (Saito and Marumoto, 2002).

Unlike the studies using dual inoculation, the results of Goss and de Varennes (2002) were never confirmed with other genera of plants or microbes. The primary objective of this study was to establish the general applicability of the original study by testing another combination of soil, legume plant, rhizobium and indigenous AMF.

Goss and de Varennes (2002) used a silt loam from Canada - a soil formed under climatic conditions of low temperatures during winter (with a snow cover during several months) and hot wet summers. The soil used in the present experiment was a clay soil from Portugal-formed under Mediterranean climate with mild wet winters (no snow) and hot dry summers. Additionally, in the present experiment the soil was supplied with $\mathrm{P}$ whereas in Goss and de Varennes (2002) no fertilizer was added although the soil also had a small content of plant available P. This modification in the experimental design would bring the conditions closer to those expected under field conditions. It might have been the reason for the lack of response between treatments in the first phase, when the differential inoculum potential for AMF was being built. The availability of $\mathrm{P}$ in the soil may not have limited wheat growth and the plants would therefore be less dependent on AMF. However, that variation may also arise from differences between the plant species used in the two experiments (maize and wheat) in the response to and stimulation of AMF. Mozafar et al. (2000) found more AMF colonization of maize in less disturbed soil but in wheat the level of disturbance did not affect the colonization. Although controlled environment studies (e.g. Hart and Reader, 2004) and some field experiments (e.g. Oehl et al., 2003) have suggested that some groups of AMF are more tolerant of soil disturbance than others, others have found no significant differences in diversity of AMF between tillage treatments (Franke-Snyder et al., 2001; Jansa et al., 2002).

Goss and de Varennes (2002) used soybean as the experimental plant, a legume native to Eastern Asia grown for its seed which has a very high protein and oil content. Soybean establishes a symbiosis with $B$. japonicum and can derive from $25 \%$ to $85 \%$ of its $\mathrm{N}$ from atmosphere (Jefing et al., 1992; Vasilas et al., 1995), although the average value in central Ontario is only approximately $40 \%$ (Ravuri and Hume, 1992). Annual medics (Medicago spp.) are small seeded legumes native to the Mediterranean basin. They are used as pastures suited to grazing in semiarid dryland farming (Crawford et al., 1989). They establish a very effective symbiosis with $S$. meliloti and can derive $60-90 \%$ of their $\mathrm{N}$ from the atmosphere (Elabbadi et al., 1996; de Varennes et al., 2001).

Our results partially agreed with the study of Goss and de Varennes (2002). In undisturbed soil, M. truncatula developed faster, had a greater $\mathrm{P}$ content (and possibly a greater $\mathrm{N}$ content) and derived more $\mathrm{N}$ from atmosphere than did plants grown in sieved soil. However, there were some major differences between the two experiments.

Root biomass of $M$. truncatula was affected by treatment. Roots were smaller in undisturbed soil (a decrease in fresh weight of $26 \%$ compared with roots from sieved soil) because the clay soil became very compact. This would compromise the capacity of the plant to extract nutrients from the soil, in particular less mobile nutrients such as $\mathrm{P}$, if it was not compensated by AMF colonization. Furthermore, sieving the soil led to increased acid phosphatase activity, while Goss and de Varennes (2002) found no differences in the activity of this soil enzyme between both treatments.

In the present experiment, the upper layers of the undisturbed soil became very compact, and although the sieved soil was packed to the sample bulk density, the pore distribution was probably very different in the two treatments. The difference in acid phosphatase activity between treatments could reflect different environments, especially the air permeability and oxygen availability. Alkaline phosphatase seems to be derived largely from microbial sources such as Bacillus subtilis (Cashel and Freese, 1964), while acid phosphatase is also released by roots (Juma and Tabatabai, 1988). As already stated, soil compaction in undisturbed soil led to a smaller root system that may have released fewer enzyme molecules.

Acid and alkaline phosphatases are important in soil organic P mineralization and plant nutrition. The greater root biomass and activity of acid phosphatase in sieved soil would be expected to lead to a greater $\mathrm{P}$ content of plants grown in this soil. As the opposite was observed, the greater $\mathrm{P}$ content in plants from undisturbed soil had to derive from the arbuscular mycorrhiza formation. However, by pod-fill the extent of AMF colonization in $M$. truncatula, as determined for hyphae, arbuscules and vesicles, was the same under both disturbance treatments. This contrasts with results for soybean (Goss and de Varennes, 2002), when disturbing the soil impaired the rate and extent of colonization, with hyphal, arbuscular and vesicular frequencies remaining greater in undisturbed soil throughout. From the two investigations we conclude that it was the rate of colonization, and not the extent, that modulated the tripartite interaction between the plant host and the microbial symbionts. 
The results obtained may have implications for fieldgrown legumes. Although soybean yields are commonly as good under no-till as under conventional tillage, AMF hyphal colonization and number of nodules were greater in young plants grown in the field under no-till compared with soil that was rotary tilled (Antunes et al., 2006c), in agreement with the results of Goss and de Varennes (2002) obtained with soybean grown in pots. This means that the need for starter $\mathrm{N}$ may be reduced or eliminated in fieldgrown legumes following the implementation of no-till, as the greater rate of early AMF colonization should stimulate the onset of $\mathrm{N}_{2}$ fixation.

\section{Conclusions}

This experiment is the first report on the effect of soil disturbance on the interaction of Sinorrhizobium, indigenous AMF and legumes. Together with previous work with soybean and Bradyrhizobium, this study suggests that the positive interaction of rhizobia, AMF and legumes is modulated by the rate of early AMF colonization, and that soil disturbance impairs this interaction by delaying the colonization of roots by the fungal partner.

\section{Acknowledgments}

This study was funded by the Portuguese government and the European Union through project POCI/AGG/ 42616/2001 from the FCT with funds from FEDER. We thank Ana Caetano Conceição and Paula Gonçalves Silva for technical assistance.

\section{References}

Abbott, L.K., Robson, A.D., Scheltema, M.A., 1995. Managing soils to enhance mycorrhizal benefits in mediterranean agriculture. Critical Reviews in Biotechnology 15, 213-228.

Antunes, P.M., de Varennes, A., Rajcan, I., Goss, M.J., 2006a. Accumulation of specific flavonoids in soybean (Glycine max (L.) Merr.) as a function of the early tripartite symbiosis with arbuscular mycorrhizal fungi and Bradyrhizobium japonicum (Kirchner) Jordan. Soil Biology \& Biochemistry 38, 1234-1242.

Antunes, P.M., Rajcan, I., Goss, M.J., 2006b. Specific flavonoids as interconnecting signals in the tripartite symbiosis formed by arbuscular mycorrhizal fungi, Bradyrhizobium japonicum (Kirchner) Jordan and soybean (Glycine max (L.) Merr.). Soil Biology \& Biochemistry 38, $533-543$.

Antunes, P.M., de Varennes, A., Zhang, T., Goss, M.J., 2006c. The tripartite symbiosis formed by indigenous arbuscular mycorrhizal fungi, Bradyrhizobium japonicum and soya bean under field conditions. Journal of Agronomy and Crop Science 192, 373-378.

Brundrett, M.C., Piché, Y., Peterson, R.L., 1984. A new method for observing the morphology of vesicular-arbuscular mycorrhizae. Canadian Journal of Botany 62, 2128-2134.

Cashel, M., Freese, E., 1964. Excretion of alkaline phosphatase by Bacillus subtilus. Biochemical and Biophysical Research Communications 16 , 541-544.

Chalk, P.M., Souza, R. de F., Urquiaga, S., Alves, B.J.R., Boddey, R.M., 2006. The role of arbuscular mycorrhiza in legume symbiotic performance. Soil Biology \& Biochemistry 38, 2944-2951.
Crawford, E.J., Lake, A.W.H., Boyce, K.G., 1989. Breeding annual Medicago species for semiarid conditions in southern Australia. Advances in Agronomy 42, 399-437.

de Varennes, A., Carneiro, J.P., Goss, M.J., 2001. Characterization of manganese toxicity in two species of annual medics. Journal of Plant Nutrition 24, 1947-1955.

Eivazi, F., Tabatabai, M.A., 1977. Phosphatases in soils. Soil Biology \& Biochemistry 9, 167-172.

Elabbadi, E., Ismaili, M., Materon, L.A., 1996. Competition between Medicago truncatula and wheat for ${ }^{15} \mathrm{~N}$ labelled soil nitrogen and influence of phosphorus. Soil Biology \& Biochemistry 28, 83-88.

Franke-Snyder, M., Douds, D.D., Galvez, L., Philips, J.G., Wagoner, P., Drinkwater, L., Morton, J.B., 2001. Diversity of communities of arbuscular mycorrhizal (AM) fungi present in conventional versus lowinput agricultural sites in eastern Pennsylvania, USA. Applied Soil Ecology 16, 35-48.

George, E., Marschner, H., Jakobsen, I., 1995. Role of arbuscular mycorrhizal fungi in uptake of phosphorus and nitrogen from soil. Critical Reviews in Biotechnology 15, 257-270

Goss, M.J., de Varennes, A., 2002. Soil disturbance reduces the efficacy of mycorrhizal associations for early soybean growth and $\mathrm{N}_{2}$ fixation. Soil Biology \& Biochemistry 34, 1167-1173.

Hart, M., Reader, R.J., 2004. Do arbuscular mycorrhizal fungi recover from soil disturbance differently? Tropical Ecology 45, 97-111.

Ibijbijen, J., Urquiaga, S., Ismaili, M., Alves, B.J.R., Boddey, R.M., 1992. Effect of arbuscular mycorrhizal fungi on growth, mineral nutrition and nitrogen fixation of three varieties of common bean. New Phytologist 134, 353-360.

Jansa, J., Mozafar, A., Anken, T., Ruh, R., Sanders, I.R., Frossard, E., 2002. Diversity and structure of AMF communities as affected by tillage in a temperate soil. Mycorrhiza 12, 225-234.

Jefing, Y., Herridge, D.F., Peoples, M.B., Rerkasem, B., 1992. Effects of $\mathrm{N}$ fertilization on $\mathrm{N}_{2}$ fixation and $\mathrm{N}$ balances of soybean grown after lowland rice. Plant and Soil 147, 235-242.

Juma, N.G., Tabatabai, M.A., 1988. Hydrolysis of organic phosphate by corn and soybean roots. Plant and Soil 107, 31-38.

McGonigle, T.P., Miller, M.H., Evans, D.G., Fairchild, G.L., Swan, J.A., 1990. A new method which gives an objective measure of colonization of roots by vesicular-arbuscular mycorrhizal fungi. New Phytologist $115,495-501$.

Mozafar, A., Anken, T., Ruh, R., Frossard, E., 2000. Tillage intensity, mycorrhizal and nonmycorrhizal fungi, and nutrient concentrations in maize, wheat, and canola. Agronomy Journal 92, 1117-1124.

Oehl, F., Sieverding, E., Ineichen, K., Mäder, P., Boller, T., Wiemken, A., 2003. Impact of land use intensity on the species diversity of arbuscular mycorrhizal fungi in agroecosystems of central Europe. Applied Environmental Microbiology 69, 2816-2824.

Ravuri, V., Hume, D.J., 1992. Performance of a superior Bradyrhizobium japonicum and a selected Sinorhizobium fredii strain with soybean cultivars. Agronomy Journal 84, 1051-1056.

Riehm, H., 1958. Die ammoniumlaktatessigsaure-methode zur bestimmung der leichtloslichen phosphosaure in karbonathaltigen boden. Agrochimica 1958, 49-65.

Saito, M., Marumoto, T., 2002. Inoculation with arbuscular mycorrhizal fungi: the status quo in Japan and the future prospects. Plant and Soil 244, 273-279.

Vasilas, B.L., Nelson, R.L., Fuhrmann, J.J., Evans, T.A., 1995. Relationship of nitrogen utilization patterns with soybean yield and seed-fill period. Crop Science 35, 809-813.

Vejsadova, H., Siblikova, D., Hrselova, H., Vancura, V., 1992. Effect of the AM fungus Glomus sp. on the growth and yield of soybean inoculated with Bradyrhizobium japonicum. Plant and Soil 140, $121-125$.

Vejsadova, H., Siblikova, D., Gryndler, M., Simon, T., Miksik, I., 1993. Influence of inoculation with Bradyrhizobium japonicum and Glomus claroideum on seed yield of soybean under greenhouse and field conditions. Journal of Plant Nutrition 16, 619-629. 